\title{
BLOOD GROUPS ABO AND Rh (D) FACTOR IN THE RHEUMATIC DISEASES
}

\author{
BY \\ I. STOIA, R. RAMNEANTU, AND M. POITAS \\ From the Methodology Centre of Rheumatology, Bucharest, Romania (Director: Professor Dr. I. Stoia)
}

The researches of Cohen, Boyd, Goldwasser, Cathcart, and Heisler (1963) on a small number of patients with chronic joint disease of different clinical types showed that there was no association between the ABO blood groups and the chronic rheumatic diseases, but that there was a deficiency of $\mathrm{Rh}$ factor. Kornstad, Kornstad, and Guldberg (1965), examining 217 patients with rheumatoid arthritis, found the distribution of ABO groups to be about the same as in a control group; the frequency of $R h$ factor was 12 per cent. compared with 16 per cent. in the controls, a difference which is not statistically significant.

Macafee (1965), reporting on 431 cases of rheumatic heart disease and on the statistical data previously published, found an excess of group A, and observed that the frequency of "non-secretors", $\mathrm{ABO}(\mathrm{H})$, was higher in cases of rheumatic fever.

\section{Material}

Since 1962 we have examined 1,454 cases, all from Bucharest, of which 701 had a clinical and serological diagnosis of rheumatoid arthritis (latex test and sheep cell agglutination test with euglobulin extracted with ammonium sulphate), 183 of ankylosing spondylitis, and 570 of degenerative joint disease.

To avoid systematic error affecting the frequency of the rarest of the four blood groups, we used the formula of Fisher to calculate the expected numbers of AB blood groups in the sample, and compared them with the observed number; we found no significant difference.

\section{Results}

Table I shows a comparison, using the $\chi^{2}$ test, of our results with those in 26,229 blood donors, also from Bucharest, who were used as controls (Mihăilescu, 1958).

In rheumatoid arthritis the frequency of group B is significantly higher than in the controls. In ankylosing spondylitis and degenerative joint disease the difference is not significant.

This fact is shown in Table II (opposite), in which the statistical method of Woolf (1955) is applied. The blood groups from the patients are:

$$
B=h ;(A+O+A B)=k \text {, }
$$

and those from the control group are:

$$
B=H ;(A+O+A B)=k \text {. }
$$

TABLE I

DISTRIBUTION OF ABO BLOOD GROUPS IN 570 CASES OF CHRONIC JOINT DISEASE

\begin{tabular}{|c|c|c|c|c|c|c|c|}
\hline \multirow[b]{2}{*}{ Blood Group } & \multicolumn{3}{|c|}{ No. of Cases } & \multicolumn{3}{|c|}{ Frequency (per cent.) } & \multirow{2}{*}{ Control Group } \\
\hline & RA & AS & $\overline{\text { DJD }}$ & RA & AS & DJD & \\
\hline Total & 701 & 183 & 570 & $99 \cdot 99$ & $100 \cdot 0$ & $100 \cdot 0$ & 26,229 \\
\hline $\mathbf{A}$ & 295 & 71 & 233 & $42 \cdot 22$ & $38 \cdot 80$ & $40 \cdot 88$ & $40 \cdot 46 \%$ \\
\hline B & 144 & 37 & 103 & $20 \cdot 54$ & $20 \cdot 22$ & $18 \cdot 07$ & $17 \cdot 19 \%$ \\
\hline 0 & 211 & 62 & 199 & $30 \cdot 10$ & $33 \cdot 88$ & $34 \cdot 91$ & $34.01 \%$ \\
\hline $\mathbf{A B}$ & 50 & 13 & 35 & $7 \cdot 13$ & $7 \cdot 10$ & $6 \cdot 14$ & $8 \cdot 33 \%$ \\
\hline \multicolumn{2}{|c|}{$\chi^{2}$ with 3 d.f. } & .. & .. & $9 \cdot 48$ & 1.43 & $4 \cdot 27$ & \\
\hline $\mathbf{P} \ldots$ & .. & .. & .. & $0.02-0.05$ & $0.5-0.7$ & $0 \cdot 20-0 \cdot 30$ & \\
\hline
\end{tabular}
AND IN A CONTROL GROUP OF 26, 229 BLOOD DONORS 
TABLE II

COMPARISON OF THE FREQUENCIES OF THE BLOOD GROUPS B AND A + O + AB

\begin{tabular}{c|c|c|c|c}
\hline$X=\frac{\mathrm{h} \times \mathrm{K}}{\mathrm{H} \times \mathrm{K}}$ & $Y$ & $W$ & $Y^{2} W$ & $\mathrm{P}$ \\
\hline 1.24534 & -0.21942 & 111.61 & 5.36855 & $0.02-0.05$ \\
\hline
\end{tabular}

We found the frequency of $R h$ (D) in 411 patients to be 12 per cent. compared with 15 per cent. in the controls. Table III shows that this difference is statistically significant.

\section{Summary}

Blood group B was found more frequently in patients with rheumatoid arthritis than in a group of blood donors used as controls.

Our finding on the frequency of the $\mathrm{Rh}$ factor confirm the conclusions of previous authors.

There is no difference between the blood groups in cases of ankylosing spondylitis and osteo-arthrosis and those in the control group.

TABLE III

FREQUENCY OF BLOOD GROUPS Rh AND rh IN 411 PATIENTS WITH RHEUMATOID ARTHRITIS COMPARED WITH A CONTROL GROUP OF 24,829 (WOOLF'S METHOD)

\begin{tabular}{|c|c|c|c|c|c|c|c|c|}
\hline \multicolumn{2}{|c|}{ RA } & \multicolumn{2}{|c|}{ Control } & \multirow{2}{*}{$X$} & \multirow{2}{*}{$Y$} & \multirow{2}{*}{$\boldsymbol{W}$} & \multirow{2}{*}{$Y^{2} W$} & \multirow{2}{*}{$\mathbf{P}$} \\
\hline $\mathbf{R h}$ & rh & $\mathbf{R h}$ & rh & & & & & \\
\hline 369 & 42 & 21,105 & 3,724 & $-0 \cdot 19030$ & 0.43819 & $37 \cdot 218$ & $7 \cdot 14616$ & $0.01-0.001$ \\
\hline
\end{tabular}

\section{REFERENCES}

Cohen, A. S., Boyd, W. C., Goldwasser, S., Cathcart, E. S., and Heisler, M. (1963). Nature (Lond.), 200, 1215 (Correlation between rheumatic diseases and $\mathrm{Rh}$ blood groups).

Kornstad, A. M. G., Kornstad, L., and Guldberg, D. (1965). Ibid., 206, 836 (Blood groups in rheumatoid arthritis).

Macafee, A. L. (1965). Ann. rheum. Dis., 24, 392 (ABO blood groups and rheumatic heart disease).

Mihăilescu, M. (1958). Viața med., 5, 905.

Woolf, B. (1955). Ann. hum. Genet., 19, 251 (On estimating the relation between blood groups and disease).

Groupes sanguins $\mathrm{ABO}$ et le facteur $\mathrm{Rh}$ (D) dans les maladies rhumatismales

RÉSUMÉ

Le groupe sanguin B fut trouvé plus souvent chez des malades atteints d'arthrite rhumatismale que chez des donneurs de sang choisis comme témoins.

Nos résultats sur la fréquence du facteur $\mathrm{Rh}$ confirment les conclusions d'autres auteurs.

Il n'y a pas de différence entre les groupes sanguins des cas de spondylarthrite ankylosante et d'ostéoarthrose et ceux des témoins.
Grupos sanguíneos ABO y el factor $\mathrm{Rh}$ (S) en las enfermedades reumáticas

\section{SUMARIO}

El grupo sanguíneo $\mathrm{B}$ fué encontrado más frecuentemente en enfermos con artritis reumatoide que en un grupo de donadores de sangre (testigos).

Nuestros resultados respecto a la frecuencia del factor $\mathrm{Rh}$ confirman las conclusiones de otros autores.

No hay diferencia entre los grupos sanguíneos de enfermos con espondilartritis anquilosante $y$ con osteoartrosis y de los testigos. 